UDC: 336.13 .051

DOI 10.26906/eip.2019.4(75).1807

JEL: F52, G30, G31, G32

\title{
STATE BUDGETARY SECURITY DETERMINANTS
}

\author{
Svitlana Onyshchenko, DSc, Assistant Professor \\ National University «Yuri Kondratyuk Poltava Polytechnic»
}

*ORCID 0000-0002-6173-4361

$\overline{\text { C Onyshchenko S., } 2019 .}$

Стаття отримана редакиією 02.12.2019 p.

The article was received by editorial board on 02.12 .2019

Introduction. The study of the state budget security determinants are of particular importance in the context of increased globalization processes. The asymmetry of globalization is caused not only by the presence of a large number of processes and their magnitude, but also by the common consequences of these processes, for which a synergistic effect is being observed. Ukraine's budgetary system demonstrates its reluctance to globalization challenges, its vulnerability to crisis phenomena and accumulation of numerous internal imbalances. The article emphasizes the fact that the most pressing problems of economic and social life of the state are concentrated in the budget sphere today, such as the chronic phenomenon of budget deficit and public debt, insufficient provision of the state budget with financial resources as well as imperfection and low efficiency of their spending distribution. There are problems of inefficient use of budget funds in the process of social protection functions performing, public administration and international activities, insufficient funding of science, education, culture and health care, and shortcomings in the investment and environmental policies implementation. The problem of national security and defense, which additionally requires considerable budgetary expenditures, is also an acute problem today.

Therefore, the problem of identifying determinants of state budget security that influence the formation of a dangerous level of state budget security is actualized.

Overview of recent researches and publications. Scientific researches and empirical studies of the state budget and financial security were considered by such scholars as O. Baranovskyi, I. Babets, O. Borodii, Z. Varnalii, O. Vlasiuk, O. Demeniuk [7-13], J. Zhalilo, M. Yermoshenko , T. Yefimenko. Budgetary security in ensuring the strategy of socio-economic development of the state is considered by O. Kolisnyk [14]. V. Martyniuk distinguishes the fiscal component and investigates threats and factors of influence [15]. Studies of theoretical analysis of budgetary security are given in the works by V. Muntian, H. Pasternak-Taranushenko, S. Pyrozhkov, and others. While appreciating the sound achievements and sufficiently high interest in the field of financial security, it should be noted that the problem of determining determinants and ensuring the budgetary security of the state, taking into account the processes of globalization, constructive / destructive influence of factors and threats, remains beyond the scholars' attention.

The purpose of the paper. The article aimed at specifying the determinants of state budget security that affect the level of security, its structure and complexity of ensuring.

The main body and results of the research. State budget security is guided by a number of determinants that specify the content, structure and level of its ensuring. Determinants of state budget security are the factors, threats of exogenous and endogenous origin and cause and effect relationships, which directly or indirectly determine its level and complexity of its processes ensuring.

Fiscal security, as an economic concept, by its appearance has completed the interpenetration process between structural and logical elements of national security theory and public finances. The concept of budget security, incorporating the features of political and economic directions, is ambivalent and can be considered both in terms of complex organizational and legal relations, as an indicator of the budget system development and effectiveness of the budget process as well as the criterion for evaluating budget policy. The basis for budget security study theoretical generalization was to identify initial categories and related concepts such as "budget", "budget process", "budget system", "security", "budget security".

Generalization of the existing interpretations of the "budget security" concept enabled determining of the concept meaning. State budget security is viewed from the standpoint of functional and protective approaches, as a prerequisite for the financial system of the state functioning, under which the budget system 
is able to ensure solvency and financial stability of the state, efficient use of budget funds, taking into account strategic priorities of budgetary relations development, has a potential capacity to confront the threats of internal and external origin and secure public finances.

Budgetary security condition is an important indicator in each country's economy. This is revealed when there are certain negative social and economic processes that arise in the course of public policy conducting. Such processes have a direct impact on the rate of budgets provision with financial resources at all levels.

Budget security operating in the country should include the influence of various factors of managing the budget system of the country and, accordingly, the quality of social and economic tasks of the state depends directly on this. Budget security is an indicator that reflects the effectiveness of fiscal policy and organization of the budget process in the country. From economic point of view, budgetary security shows how the state is able, through the budget, to fulfill its functions and powers and to meet the needs of taxpayers and budgetary institutions, taking into account public interest. Thus, ensuring budgetary security is one of the priorities of the state in the process of ensuring its socio-economic development vector.

The objects of attention while ensuring the budgetary security of the state are the state budget execution, efficiency of budgetary resources use, the budget process and the budget system. State budget security entities are public authorities acting in accordance with existing financial institutions, using budgetary policy instruments aimed at implementing a safe level of budgetary security. The main results of ensuring the budgetary security of the state are stability of public finances, balance of the state budget, efficient use of budgetary funds, balance of external and internal debt, under which the necessary financial conditions are created for stable socio-economic development of the country.

Sources of budget security threats are the conditions and factors that lead to the budget system deformation. There are many destructive circumstances affecting the budgetary security and effectiveness of the state's budgetary policy. All risk factors can be grouped according to certain classification characteristics.

Given the various types of threats to the state's budget security, they can all be distinguished as exogenous (external) and endogenous (external). Threats to the budgetary security of the state impede the realization of budgetary interests, priorities, budget programs and lead to formation of negative preconditions and factors in the budgetary process and budgetary system. Threats have the following classification features: according to the stages of the budget process (threats at the stages of drafting the budget, review and approval, budget execution, control); nature of breach of budget interests (caused by single and numerous breaches); the scale of destabilization (national, local, individual); duration of destructive effects (systemic, additional acquired); imbalance (threats to the revenue side, threats to the expenditure side, threats to financing the budget deficit, threats to debt dependency) (threats to the stage of revenue generation, threats to the use of the expenditure part, threats to the budget deficit, threats to debt dependence), negative impact on the budget debt itself. Imbalance threats are considered as a set of challenges, risks, factors that arise at different stages of the budget process and complicate or prevent the implementation of budgetary policy.

Considering the above threats, it can be clearly stated that effectiveness of the state budget security is determined by a certain list of determinants (Fig. 1).

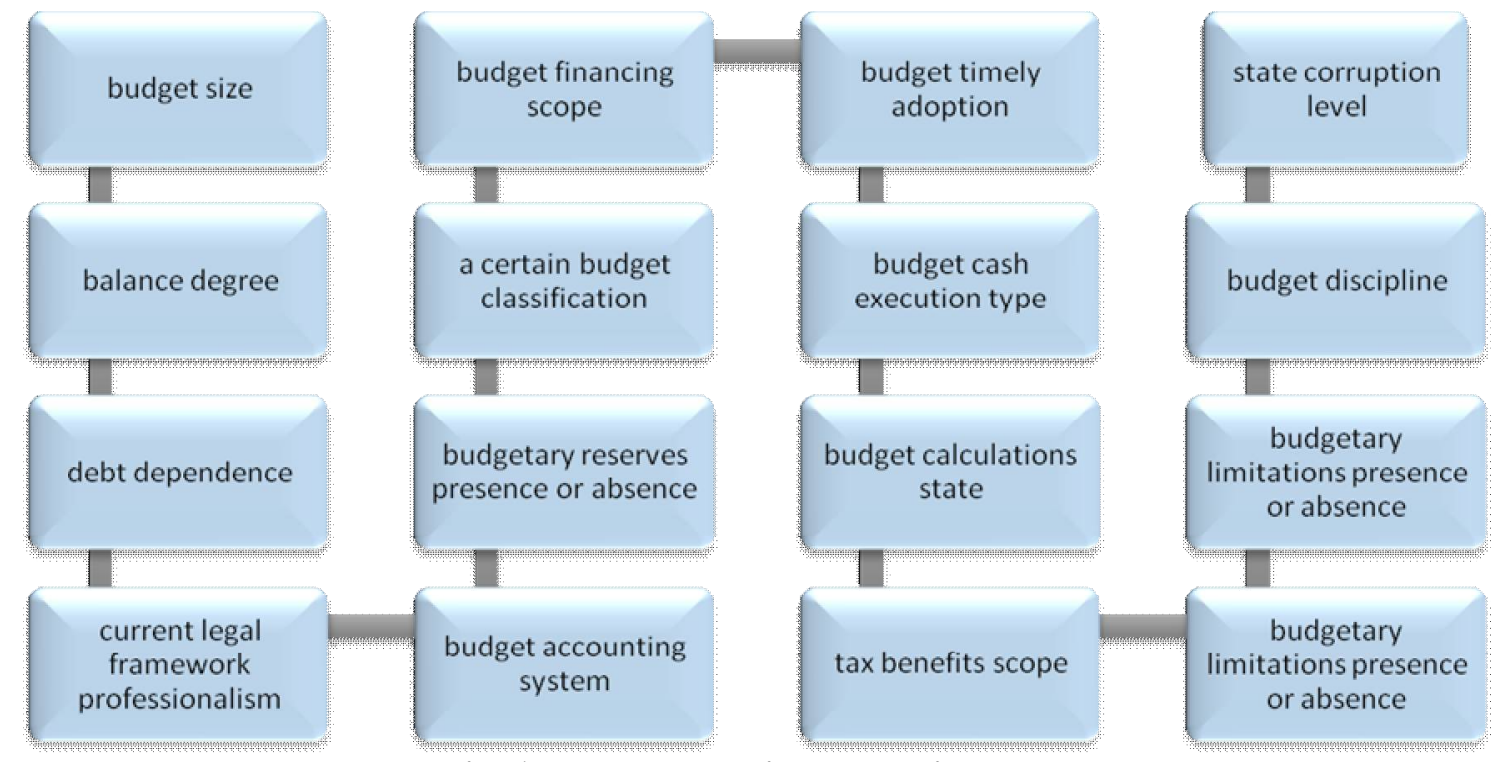

Fig. 1. Budget security determinants

* Compiled according to data [8; 9; 10] 
Thus, it was found that the possibility of ensuring budgetary security is dictated by the existing mechanism of its formation, which is formed in the process of budgetary policy making. Therefore, it is considered expedient to reveal in more detail the content of state budget security determinants.

Budget size. This indicator is the most ambitious, since the financial support of budgetary activity reveals the ability or inability of the state to fully perform the functions assigned to the state and to enable its socio-economic development.

However, it should be noted that problems do not always end with insufficient resources. A major problem is the imperfection in planning and anticipating all necessary and probable expenditures at different budgets levels. Making unreasonable budgetary decisions leads to frequent changes in targeted funds usage, depending on current needs. In turn it can lead to corrupt actions in the process like budget allocation change. Such conditions lead to lack of predictability in the state budget and to under-financing of important economic and social processes in the country.

A significant determinant is balance degree in the budget, which involves estimating deficit size or budget surplus. This parameter determines the ability of the state to finance plans implementation for major expenditures and repayment of public debt at revenue generated expense. In such circumstances, budgetary security level is defined as the inverse indicator to the level of the budget deficit. That is, budget deficit growth causes a decline in the state budgetary security and vice versa. The ideal formula is a completely deficit-free budget, which did not happen to the domestic economy, over the studied period of time.

The budgetary security of the state and local communities, economic entities and households is undoubtedly influenced by taxation existing level and its sustainability over time. No wonder the French enlightener and philosopher Charles Louis Montesquieu stated: "Nothing requires as much wisdom and reason as the determination of the part they take away from the subjects and the one they are left with" [16].

If to consider such a determinant as a valid budget system, it should be noted that it is reflected in the impact size of budgets interconnection at different levels. It demonstrates the need to take into account the security situation at both the national and regional levels and draw a constant parallel to implementation state consolidated budget and to take into account their mutual indebtedness. One of the central issues today is ensuring maximum autonomy of local budgets, which is aimed at decentralization reform, which has been actively implemented in recent years.

Existing legislative and institutional support, professionalism and careful procedure of budget development, review and approval have an important influence. It is reflected in the degree of consideration of all exceptions and features of all stages of budgeting, timely adoption of projects, reports and delegation of authority and seriousness of approaches to the approval of all parameters and values in the state budget law. A striking example is the United States, where legislation does not enable allocation of expenditures without an approved and signed state budget law.

Budgetary financing magnitude is a manifestation of the redistribution of budgetary funds, within the framework of this process; public funds are provided economic entities to support their break-even financial activities. It should be noted that this process (providing budget financing) is inversely proportional to budgetary security level.

Last but not least is the choice of budget classification, which is the distribution of income and expenses by groups, characterized by common characteristics and areas of application.

The degree of budgetary security of the state increases or decreases in the presence / absence of budgetary reserves, that is, funds formed in the state budget for continuous financing of the planned measures and ensuring of urgent new expenses. At the same time, foreign economic literature also includes the term fiscal space, which is defined as a budget reserve that can be used for certain purposes without sacrificing financial position or economic stability. Fiscal space concept has been developed by the IMF and is considering the possibility of increasing it at the national level without affecting domestic budgetary regulation $[10$, p. 50$]$.

It is worth noting that, in the absence of a perfect budgetary account, there is a greater possibility of losing the ability to identify financial and timely financial threats and risks that can be met by insufficient financial resources. Low budgeting reduces budget process transparency and makes it impossible to carry out quality controls in the budgetary area. 
Budgetary security depends on the budget timely adoption, since delays in the budgetary process may be the main factor destabilizing. Among the direct consequences of budget untimely adoption is disorganization in the socio-economic sphere, investment activity further reduction, inflationary processes intensification, national currency destabilization, and citizens' income depreciation [20]. Budget security is also conditioned by the timeliness of budget payments.

Budgetary discipline is a somewhat general determinant, which includes taking into account all the above requirements and the competence and integrity of the bodies involved in the allocation of budgetary resources and budgetary decisions added to it. Compliance with budgetary discipline can be ensured by strengthening the control over the actions of the legislative and executive bodies [21].

Important for the state budgetary security is the likelihood of budget crises and, in fact, the specifics behind which budgetary movements occur. All of these factors contribute to the error proportion that arises when the state implements its budgetary policy.

Conclusions. While conducting the research it was proved that economic security has a wide range of components, among which there is budget security of the state. This concept includes the condition of the state solvency, taking into account the balance of state revenues and expenditures, and ability to effectively manage budgetary resources, by promptly responding to internal and external threats to stability and steadiness of the budget system. Determinants of state budget security influence the socio-economic development of the state and are indicators and criteria for the budget policy effectiveness and organization of the budget process.

The main determinants of the impact on the budgetary security of the state have been systematized, taking into account the globalization processes and multicriteria of the existing factors and threats of both exogenous and endogenous origin.

\section{REFERENCES:}

1. The World Economic Forum (2015). The Global Competitiveness Report. Retrieved from http://www.weforum.org/reports

2. European Commission (2015). Europe 2020: European Union's ten-year growth strategy. Retrieved from http://ec.europa.eu/europe2020/index_en.htm

3. The World Bank (2013). Indicators. Retrieved from http://www.worldbank.org/

4. State Statistics Service of Ukraine (2015). Statistic information. Retrieved from http://www.ukrstat.gov.ua/ (in Ukr.).

5. Luciani, J. (1988). The Economic Content of Security (Working Paper No 2, Vol. 8). Retrieved from http://jpublicpolicy.com/

6. Cable, V. (1995). What Is International Economic Security? (Working Paper No 2, Vol. 71). Retrieved from http://en.interaffairs.ru/

7. Babets I.H. (2013). Methodological approaches to safety assessment of fiscal Ukraine / / Scientific Journal NLTU Ukraine. 23 (in Ukr.).

8. $\quad$ Baranovskyi, O. I. (2014). Security philosophy: monograph: in 2 t. Kyiv: UBS. NBU (in Ukr.).

9. Onyshchenko, S.V, 2017. Budget security of Ukraine: the essence, threats and ways of providing:. Kyiv: Znannia Ukrainy,. pp. 39-93.

10. Varnalii, Z.S. Byudzhetnyi protses $v$ Ukraini: stan ta problemy instytutsiinoho zabezpechennia : monohrafiia / Z.S. Varnalii, T.V. Buhai, S.V. Onyshchenko. - K. ; Poltava : PoltNTU, 2014. - 270 s. (in Ukr.).

11. Vlasiuk O. S. Teoriia i praktyka ekonomichnoi bezpeky v systemi nauky pro ekonomiku (Theory and practice of economic security in the sciences of economics) [Text]: / O. S. Vlasiuk; Nats. in-t probl. mizhnar. bezpeky pry Radi nats. bezpeky i oborony Ukrainy (Nat. Inst. International Security at the National Security and Defense Council of Ukraine). - K., 2008. - P. 43-46.

12. Pension Fund Deficit in 2014 - 2019 // The Word and Work Analytical Portal [Electronic resource]. - Retrieved from https://www.slovoidilo.ua/2019/09/26/infografika/finansy/deficyt-pensijnohofondu-2014-2019-rokax. 
13. Demenok O.V., Glukhov V.I. (2010). Ukraine security budget as part of the financial security of the state: state and prospects. Retrieved from http://www.nbuv.gov.ua/portal/soc_gum/nie/2010_1/016022.pdf.

14. Kolesnik O.J.(2009) Budget to ensure security of socio-economic development: Thesis. Dis. candidate. Econ. Sciences specials. Ternopil. (in Ukr.).

15. Martyniuk V. (2013). Assessment of the national economy based on the integral index of economic security. Economics, management, entrepreneurship, 25 (I), 179-188 (in Ukr.).

16. More than $38 \%$ of Ukrainian entrepreneurs are dissatisfied with the current state of business [Electronic resource]. - Retrieved from https://agropolit.com/news/11491-ponad-38-ukrayinskihpidpriyemtsiv-nezadovoleni-potochnim-stanom-sprav-u-biznesi (in Ukr.).

17. Sukhorukov, A., \& Ostapchuk, D. (2014). Synergetic mechanism of the state economic security system formation. Ekonomichnyi Casopys-XXI (Economic Annals-XXI), 1-2(1), $19-22$ (in Ukr.)

18. Ministry of Economic Development and Trade of Ukraine (2013). Economic situation and forecasts. Retrieved from http://www.me.gov.ua/ (in Ukr.)

19. Onyshchenko, S. \& Puhach, A. (2015). Threats to economic security of Ukraine: essence, evaluation and prevention mechanism. Poltava: PoltNTU (in Ukr.)

20. Onyshchenko, S. V. Orhanizatsiino-ekonomichnyi mekhanizm uperedzhennia zahroz byudzhetnii bezpetsi ekonomiky Ukrainy/ S. V. Onyshchenko, O. A. Maslii // Naukovyi visnyk «Polissia». - Chernihiv : Chernihiv. nats. tekhnol. un-t, 2017. - № 1 (9), ch.1. - S. 176-184. (in Ukr.).

21. Onyshchenko, S. Financial security hazards of ukraine: identification and systematization / S. Onyshchenko, O. Maslii, Maksymenko A.P.// Economic\& Regions. - 2019. - №2 (73). - P. 72-80. (in Ukr.).

\section{УДК: 336.13.051}

JEL: F52, G30, G31, G32

Онищенко Світлана Володимирівна, доктор економічних наук, доцент. Національний університет «Полтавська політехніка імені Юрія Кондратюка». Детермінанти бюджетної безпеки держави. Бюджетна безпека держави обумовлюється низкою детермінантів, які визначають зміст, структуру та рівень ії забезпечення. Визначено, що визначальними фактами забезпечення державного бюджету є фактори, загрози як екзогенного, так і ендогенного походження, а також причиннонаслідкові зв'язки, які прямо чи опосередковано визначають його рівень та складність процесів його забезпечення.

Запропоновано перелік основних детермінант, що впливають на забезпечення бюджетної безпеки держави з урахуванням процесів глобалізації, конструктивного / руйнівного впливу факторів та загроз. Зазначається, що систематичним елементом забезпечення державного бюджету $\epsilon$ державний бюджет, який $є$ багатогранним поняттям. Бюджет як інструмент державної політики відіграє ключову роль у забезпеченні соціально-економічного розвитку держави, реалізації іiі національних інтересів, а саме на обсяг та структуру дохідної та видаткової частини бюджету впливають на функціонування всіх галузей економіка.

Обгрунтовується необхідність забезпечення бюджетної безпеки як складової соціальноекономічного розвитку та передумовою здійснення ефективної державної фінансово-економічної політики як основи досягнення національних економічних інтересів держави.

Систематизовано основні детермінанти впливу на бюджетну безпеку держави з урахуванням глобалізаційних процесів та багатокритерії існуючих факторів та загроз як екзогенного, так i ендогенного походження.

Ключові слова: безпека державного бюджету, детермінанти бюджетної безпеки, загрози. 
UDC: 336.13 .051

JEL: F52, G30, G31, G32

Onyshchenko Svitlana, DSc in Economics, Associate Professor. National University «Yuri Kondratyuk Poltava Polytechnic». State Budgetary Security Determinants. Budgetary security of a state is stipulated by a number of determinants that specify the content, structure and level of its provision. It is defined that the determinants of the state budget security are the factors, threats of both exogenous and endogenous origin as well as cause and effect relationships, which directly or indirectly determine its level and complexity of the processes of its ensuring. The list of the main determinants influencing the ensuring the budget security of the state taking into account the processes of globalization, constructive / destructive influence of factors and threats is offered. It is noted that the systematic element of the state budget security is the state budget, which is a multifaceted concept. The budget as an instrument of public policy plays a key role in ensuring the socio-economic development of the state, realization of its national interests, namely the volume and structure of the revenue and expenditure parts of the budget affect the functioning of all sectors of the economy. The necessity of ensuring budgetary security as a component of socio-economic development and the prerequisite for the implementation of effective state financial and economic policy as a basis for achieving the national economic interests of the state is substantiated. The main determinants of the impact on the budgetary security of the state have been systematized, taking into account the globalization processes and multicriteria of the existing factors and threats of both exogenous and endogenous origin.

Key words: state budget security, determinants of
budget
УДК: 336.13 .051

JEL: F52, G30, G31, G32

Онищенко Светлана Владимировна, доктор экономических наук, доцент. Национальный университет «Полтавская политехника имени Юрия Кондратюка». Детерминанты бюджетной безопасности государства. Бюджетная безопасность государства обусловлена рядом факторов, определяющих содержание, структуру и уровень ее обеспечения. Определено, что определяющими факторами безопасности государственного бюджета являются факторы, угрозы как экзогенного, так и эндогенного происхождения, а также причинно-следственные связи, которые прямо или косвенно определяют его уровень и сложность процессов его обеспечения. Предложен перечень основных детерминант, влияющих на обеспечение бюджетной безопасности государства с учетом процессов глобализации, конструктивного / разрушительного воздействия факторов и угроз. Отмечается, что системным элементом обеспечения государственного бюджета является государственный бюджет, который является многоплановым понятием. Бюджет как инструмент государственной политики играет ключевую роль в обеспечении социальноэкономического развития государства, реализации его национальных интересов, а именно объем и структура доходной и расходной частей бюджета влияют на функционирование всех отраслей экономики. Обоснована необходимость обеспечения бюджетной безопасности как составной части социально-экономического развития и предпосылки реализации эффективной государственной финансово-экономической политики как основы достижения национальных экономических интересов государства. Основные детерминанты влияния на бюджетную безопасность государства были систематизированы с учетом процессов глобализации и многокритериальности существующих факторов и угроз как экзогенного, так и эндогенного происхождения.

Ключевые слова: безопасность государственного бюджета, детерминанты бюджетной безопасности, угрозы. 